Jurnal Care Vol .6, No.1,Tahun 2018

\title{
Keton Urin Bersalin Berhubungan Dengan Asupan Nutrisi
}

\author{
Rika Resmana ${ }^{1}$ Dian Nur Hadianti ${ }^{2}$ \\ 1,2 Politeknik Kesehatan Kemenkes Bandung Jurusan Kebidanan Bandung \\ Jalan Sederhana No.2, Bandung, Jawa Barat \\ e-mail: rika_resmana@yahoo.com
}

\begin{abstract}
Hypertonic uteric can lead to muscle fatigue that leads to increased ketones levels. Give adequate nutritional intake is one of the efforts for contraction which is balanced with the strength of optimal labor and keton urine normal baseline. The purpose of this study was to analisis the relationship between nutritional intake with keton urine of labor. This type of study is cross-sectional study. Population are intranatal was 32 respondents. Nutrient intake data were collected using observation sheets by observing all nutrient intake from 4 or 5 start up until the onset of labor. Urine ketone data was collected by checking maternal urine using keto strip. Data were analized using, and the data obtained were analyzed univariat and bivariate. The bivariant data were analyzed using Chi Square test. The research result is there a relationship of nutritional intake with keton urin in labor with $p$ value 0,049 $(p<0.05)$. The research result keton urine of labor associated with nutrition intake.
\end{abstract}

Keywords: nutritional intake; intranatal; keton urine

\begin{abstract}
ABSTRAK
Kontraksi otot pada ibu bersalin yang berlangsung lama dapat mengakibatkan kelelahan otot yang berujung terhadap adanya peningkatan kadar keton. Pemberian asupan nutrisi yang adekuat merupakan salah satu upaya agar his pada ibu bersalin dapat bereaksi secara efektif yang diimbangi dengan kekuatan persalinan yang optimal dan keton urin normal. Penelitian ini bertujuan untuk menganalisis hubungan asupan nutrisi dengan keton urin ibu bersalin Jenis penelitian ini menggunakan pendekatan cross-sectional. Populasi penelitian adalah ibu bersalin kala I dengan jumlah sampel yang digunakan 32 responden. Pengambilan sampel menggunakan consecutive sampling Data asupan nutrisi dikumpulkan menggunakan lembar observasi dengan cara diamati seluruh asupan nutrisi dari mulai pembukaan 4 atau 5 sampai terjadinya proses persalinan. Data keton urin dikumpulkan dengan cara memeriksakan urin ibu bersalin dengan menggunakan keto strip. Data dianalisis menggunakan uji chi square. Hasil analisis data menunjukkan terdapat hubungan antara asupan nutrisi dengan ketonuria ibu bersalin dengan $\mathrm{p}$ value $0,049(<0,05)$. Kesimpulan penelitian bahwa keton urin ibu bersalin berhubungan dengan asupan nutrisi.
\end{abstract}

Kata kunci : asupan nutrisi; ibu bersalin; keton urin 


\section{PENDAHULUAN}

Persalinan adalah proses bayi, plasenta dan selaput ketuban keluar dari uterus ibu. Sedangkan persalinan dan kelahiran normal adalah proses pengeluaran janin yang terjadi pada kehamilan cukup bulan, dengan lahir spontan dan presentasi belakang kepala yang berlangsung dalam 18 jam, tanpa komplikasi baik pada ibu maupun pada janin (Saifuddin, 2006).

Proses persalinan merupakan suatu proses perjuangan seorang ibu dalam pengeluaran hasil konsepsi dari Rahim ibu melalui jalan lahir, yang kemudian janin dapat hidup ke dunia luar. Proses persalinan sangat berkaitan dengan 5P yaitu passage way (jalan lahir), passanger (janin, plasenta dan selaput ketuban), position (posisi letak janin dan ibu), psicologic (psikologi ibu) dan power (kekuatan ibu saat mengedan) (Mochtar, 2011). Kekuatan atau power dapat diperoleh dari makanan yang mengandung energy, hal ini dijelaskan dalam penelitian Zuliyanti (2009) bahwa makanan yang mengandung energy dalam bentuk susu dan madu pada ibu intranatal akan menambah kekuatan meneran pada ibu sehingga tidak terjadi partus lama, di karenakan adanya factor power atau kekuatan ibu. Menurut (Chapman, 2006) Faktor untuk meningkatkan kontraksi uterus dengan cara non farmakologi diantaranya menambah asupan cairan dan nutrisi.

Ketika proses persalinan berlangsung, ibu memerlukan stamina dan kondisi tubuh yang prima. Metabolism pada ibu bersalin akan mengalami peningkatan, hal tersebut diakibatkan terjadinya peningkatan kegiatan otot tubuh yang disertai dengan adanya kecemasan. Kegiatan otot tubuh ibu saat mengedan memerlukan energi yang optimal. Dengan energi yang optimal, ibu akan mendapatkan kekuatan atau energy yang optimal pula (Rohani, 2011). Hasil penelitian Soviyati (2015) menyatakan bahwa ibu yang mempunyai kekuatan yang kurang baik sebagian besar $(84,1 \%)$ lama persalinannya lebih dari 18 jam.

Pemenuhan cairan dan nutrisi yang adekuat pada ibu bersalin belum ada ketentuan secara pasti. Tim Investigator Walter Reed Army Medical Center menyatakan bahwa kebutuhan energy untuk ibu bersalin belum ada data yang sudah ditentukan dengan pasti, namun kebutuhannya dapat diidentikkan dengan seorang ibu yang sedang melakukan latihan aerobic secara terus menerus. Ibu bersalin membutuhkan kurang lebih 50- 
100 kilokalori energy setiap jam (Manuaba, 2010).Kebutuhan tersebut harus terpenuhi karena jika glukosa dalam tubuh ibu bersalin tidak tersedia, maka cadangan lemak dalam tubuh ibu akan digunakan. Penggunaan cadangan lemak sebagai sumber energy prosesnya tidak sempurna dan menghasilkan sisa metabolisme yang dapat menyebabkan ketosis atau ketonuria. (Almatsier 2003) Ketosis adalah proses metabolisme yang normal. Saat tubuh tidak memiliki persediaan karbohidrat yang cukup untuk dibakar sebagai energi bagi sel-sel, maka tubuh akan membakar cadangan lemak. Kondisi inilah yang dimaksud dengan ketosis. (Veratamala, 2017)

Berdasarkan hasil survey pendahuluan yang dilaksanakan di beberapa BPS di Kota Bandung, menunjukkan bahwa asupan nutrisi pada ibu bersalin primigravida 55\% tidak adekuat. Rasa sakit yang sangat kuat merupakan salah satu penyebab ibu bersalin tidak dapat mengkonsumsi nutrisi secara adekuat. Dampak dari ketidakcukupan nutrisi akan berakibat terhadap adanya pembakaran lemak tubuh yang berlebihan, yang mengakibatkan metabolisme menjadi tidak sempurna. Metabolisme tubuh yang tidak sempurna akan mensisakan bahan bahan keton. American College of sport medicine menyatakan ibu bersalin dianjurkan untuk banyak minum dengan jenis minuman yang cukup mengandung karbohidrat. Hasil penelitian Scrutton et al (1999) yaitu bahwa ibu yang hanya minum air putih saat bersalin menunjukkan peluang lebih besar untuk terjadi ketosis pada akhir persalinan dan terjadi penurunan kadar glukosa dan insulin.

Aktifitas uterus dapat menurun akibat akumulasi benda keton yang akan berdampak pada his inadekuat dan akan mengganggu proses kemajuan dalam persalinan (Manuaba, 2010). Hasil penelitian Dwy (2014) menunjukkan bahwa ada pengaruh yang signifikan dari pemberian air kelapa muda terhadap persalinan. Pemberian air kelapa muda $250 \mathrm{ml}$ pada ibu intranatal dapat menambah asupan nutrisi dan energy sehingga dapat mengurangi ketosis dalam persalinan. Pemberian air kelapa juga dapat meningkatkan kekuatan his kontraksi pada saat bersalin, sehingga persalinan menjadi tidak berlangsung lama.Tujuan dari penelitian ini ingin mengetahui hubungan asupan nutrisi dengan keton urin pada ibu bersalin. 


\section{METODE PENELITIAN}

Jenis penelitian ini menggunakan pendekatan cross sectional study dengan menggunakan populasi seluruh ibu bersalin kala I dengan pembukaan 4 dan 5 di Puskesmas Kota Bandung yaitu Puskesmas Garuda, Puskesmas Ibrahim Adji, Puskesmas Padasuka, Puskesmas Puter, dan Puskesmas Pagarsih. Jumlah sampel yang diperlukan berjumlah 32 responden. Pengambilan sampel menggunakan consecutive sampling, dimana populasi yang menjadi sampel penelitian adalah seluruh populasi yang memenuhi inklusi dan eksklusi sampai jumlah sampel yang diperlukan terpenuhi. Selain ibu bersalin kala I dengan pembukaan 4 dan 5, juga usia kehamilan sampel aterm (37-42 minggu). Variabel dalam penelitian ini adalah asupan nutrisi dan keton urin.

Teknik mengumpulkan data variabel menggunakan Instrumen berupa lembar observasi. Data asupan nutrisi dikumpulkan oleh observer menggunakan lembar observasi dengan cara mengamati seluruh asupan nutrisi (makanan dan minuman yang dikonsumsi) dari mulai ibu bersalin ada dalam pembukaan 4 atau 5 sampai ibu bersalin tersebut mengalami proses persalinan dan hasil pengamatan itu ditulis pada lembar observasi. Data keton urin dikumpulkan dengan cara memeriksakan urin ibu bersalin dengan menggunakan keto strip. Urin ibu bersalin ditampung sesaat setelah ibu mengalami persalinan, dan selanjutnya celupkan keto strip pada urin tersebut sampai batas celup, kemudian angkat dan langsung diamati dengan cara membandingkan perubahan warna yang terjadi dengan standar warna kandungan keton urin yang tersedia dalam kemasan keton dipstick. Jika warna berubah menjadi warna lembayung maka uji keton dinyatakan positif. Selanjutnya data hasil observasi dilakukan pengolahan data dan dianalisis dengan menggunakan uji chi-square $\alpha \quad 0,05$.

\section{HASIL}

Berikut ini adalah hasil pengolahan dan analisa data. Berdasarkan Tabel 1, hasil analisis data menunjukkan bahwa asupan nutrisi pada ibu bersalin berhubungan dengan keton urin dengan p-value 0,049.

\section{PEMBAHASAN}

Hasil penelitian ini menunjukkan bahwa 28,1\% asupan nutrisi ibu bersalin tidak sesuai kecukupan dan dari ibu bersalin tersebut sebagian besar 77,8\% mengalami positif kandungan keton dalam urinnya. Demikian juga pada ibu bersalin yang asupan nutrisi selama persalinannya 
tercukupi, sebanyak 66,2\% hasil dengan nilai Odds Ratio sebesar 6,563 pemeriksaan keton urin menunjukkan negativ. Hasil analisis menggunakan uji chisquare menunjukkan hasil <0,05 yang artinya terdapat hubungan asupan nutrisi yang artinya bahwa ibu bersalin yang nutrisinya tidak tercukupi berisiko sebesar 6,56 kali mendapatkan kandungan keton dalam urinnya positif.

dengan keton urin pada ibu bersalin

Tabel 1. Hubungan Asupan Nutrisi dengan Keton Urin di Wilayah Puskesmas Kota Bandung di Wilayah Puskesmas Kota Bandung

\begin{tabular}{|c|c|c|c|c|c|c|c|c|}
\hline \multirow{3}{*}{ Asupan Nutrisi } & \multicolumn{4}{|c|}{ Ketonuria } & \multirow{2}{*}{\multicolumn{2}{|c|}{ Total }} & \multirow{3}{*}{$\begin{array}{l}\mathrm{P} \\
\text { Value }\end{array}$} & \multirow{3}{*}{$\begin{array}{l}\text { OR } \\
\text { (CI) }\end{array}$} \\
\hline & \multicolumn{2}{|c|}{ Keton positif } & \multicolumn{2}{|c|}{ Keton negatif } & & & & \\
\hline & $\mathrm{n}$ & $\%$ & $\mathrm{n}$ & $\%$ & $\mathrm{n}$ & $\%$ & & \\
\hline Tidak cukup & 7 & 77,8 & 2 & 22,2 & 9 & 100 & 0,049 & $\begin{array}{l}6,563 \\
(1,09-39,32)\end{array}$ \\
\hline Cukup & 8 & 34,8 & 15 & 66,2 & 23 & 100 & & \\
\hline Jumlah & 15 & 46,9 & 17 & 53,1 & 32 & 100,0 & & \\
\hline
\end{tabular}

Hasil penelitian tersebut menunjukkan bahwa kecupun nutrisi ibu bersalin berhubungan dengan kandung keton urin. Dari hasil penelitian tersebut dianjurkan ibu bersalin untuk memenuhi kebutuhan kalorinya sebagai upaya untuk mengurangi penggunaan energy cadangan yang diperlukan tubuh ibu bersalin saat memerlukan energy untuk kekuatan dalam meneran Kebutuhan tersebut harus terpenuhi dari makanan atau minuman dari luar karena jika glukosa dalam tubuh ibu bersalin tidak tersedia, maka cadangan lemak dalam tubuh ibu akan digunakan.
Penggunaan cadangan lemak sebagai sumber energy prosesnya tidak sempurna dan menghasilkan sisa metabolisme yang dapat menyebabkan ketosis atau ketonuria. (Almatsier,2003). Hal ini seiring dengan hasil penelitian Scrutton et al (1999) bahwa ibu yang hanya minum air putih saat bersalin menunjukkan peluang lebih besar untuk terjadi ketosis pada akhir persalinan. Demikian pula hasil penelitian Noer (2014) bahwa ada pengaruh yang signifikan dari pemberian air kelapa muda terhadap persalinan. Pemberian air kelapa muda $250 \mathrm{ml}$ pada ibu intranatal dapat menambah asupan nutrisi dan energy yang berdampak dapat mengurangi ketosis 
dalam persalinan. Pemberian air kelapa juga dapat meningkatkan kekuatan his kontraksi pada saat bersalin, sehingga persalinan menjadi tidak berlangsung lama.

Secara teori wanita bersalin membutuhkan kurang lebih 50-100 kilokalori energi setiap jam (Manuaba, 2010), Ibu bersalin yang hanya meminum air putih saat bersalin, kebutuhan kalorinya tidak terpenuhi, sehingga kebutuhan energy yang diperlukan terutama untuk memberikan kekuatan saat meneran akan menggunakan cadangan lemak yang tersedia.

Menurut Chapman(2006) faktor untuk meningkatkan kontraksi dengan cara non farmakologi diantaranya yaitu menambah asupan cairan dan nutrisi. Asupan oral makanan dan minuman sangatlah dibutuhkan oleh ibu bersalin untuk memperoleh tenaga atau kekuatan untuk meneran, menghindari kelelahan yang berakibat dehidrasi, serta menjamin kesejahteraan ibu dan janin. Bentuk makanan atau nutrisi yang sangat dianjurkan diberikan pada ibu bersalin yaitu makanan dalam bentuk konsistensi cair yang mengandung kalori tinggi, karena makanan tersebut akan mudah diabsorpsi dan American College of sport medicine menyatakan ibu bersalin dianjurkan untuk banyak minum dengan jenis minuman yang cukup mengandung karbohidrat.

\section{KESIMPULAN}

Berdasarkan hasil penelitian dapat disimpulkan bahwa keton urine pada ibu bersalin berhubungan dengan asupan nutrisi

\section{REFERENSI}

Almatsier, Sunita.(2003). Prinsip Dasar Ilmu Giz̨i. Jakarta : PT. Gramedia Pustaka Utama

Chapman, Vicky. (2006). Asuhan Kebidanan Persalinan dan Kelahiran. Jakarta: Buku Kedokteran EGC

Zuliyanti,I.,Nurma (2009). Pengarub Pemberian Susu dan Madu Pada Ibu Intranatal Terbadap Lamanya Kala II Di Rumah Sakit Bersalin Kharisma Husada Kartasura Sukoharjo

Manuaba (2010). Proses Terjadi Persalinan, Ilmu Kebidanan Penyakit Kandungan dan KB. Jakarta. EGC.

Mochtar, R (2011). Sinopsis Obstetri third edition. Jakarta. EGC

Dwy, Noer Ainny.(2014). Efektivitas Pemberian Air Kelapa Muda Terhadap Lama Persalinan Kala II Pada Ibu Intranatal

Rohani, Saswita, dan Marisah. (2011). Asuban Kebidanan Pada Masa Persalinan Jakarta: Salemba Medika 
Saifuddin, AB, (2006). Buku Acuan

Nasional Pelayanan Kesehatan

Maternal dan Neonatal. Jakarta:

Yayasan Pustaka Sarwono

Prawirohardjo.

Scrutton, et. al .(1999) Eating In Labour.

A Randomised Controlled Trial Assessing The Risks And Benefits. Journal Of The Association Of Anaesthetists Of Great Britain And Ireland. Volume 54, pages 329-334

Soviyati, Evi. (2015). Faktor Faktor Yang Berbubungan Dengan Lama Persalinan Di RSUD '45 Kuningan Jawa Barat 2015

Veratamala, Arinda. (2017) Mengenal Ketosis : Saat Tubub Membakar Lemak Sebagai Energi. Data medis direview oleh dr. Yusra Firdaus. Available from

http://hellosehat.com/hidupsehat/nutrisi/diet-ketosis-lemaksebagai-energi/ 